\title{
Study on the Present Situation and Cause of Formation of Rocky Desertification in Xichuan County
}

\author{
Sensen $\mathrm{Li}^{*}$, Hongwei Du and Weirui Chu \\ School of Civil Engineering, Nan Yang insititute of Technology, NanYang, China \\ "Corresponding author: 402894195@qq.com.org
}

\begin{abstract}
As the eco-environmental security guarantors for water source, Xichuan and its hydroecological condition play important roles in Middle Route Water Transfers Project from South to North. Via analyzing the soil, water quality, rock and vegetation et al., we studied the current extend of rocky desertification in Xichuan. Considering the local situation, we analyzed the human factors and natural factors that contribute to the rocky desertification in Xichuan, which are helpful in reducing rocky desertification and worthy of promoting.
\end{abstract}

Key Word. Rocky Desertification, Present Situation, Cause Analysis.

\section{Foreword}

Xichuan County, Nanyang City, is adjacent to Danjiangkou reservoir bank. It is the water source ecological environment security area for the water diversion project in the middle line of South-to-North Water Diversion Project, and the last barrier to purify the inflow of water. Perfect soil and water conservation at the local place has a decisive role for ensuring the water quality. Due to the influence of various factors, there is a big proportional of rocky desertification area in Xichuan County, and rocky desertification area causes very great potential risk to the water quality in reservoir area.

The rocky desertification in Xichuan County of Nanyang City not only affects the water quality of the water source in the middle line of South-to-North Water Diversion Project, but also degrades the fertility of local soil and affects the local agricultural and forestry economy. The combination of the control of rocky desertification with the improvement of the living conditions of farmers is beneficial to the local social and economic development.

\section{The Status of Rocky Desertification in Xichuan County}

Xichuan County has stretching mountains, various rivers and steep slopes and deep valleys throughout the territory. It has total area of 2820 square kilometers, most of which is located within Danjiangkou reservoir basin. The hilly area covers 1815 square kilometers (2.723 million $\mathrm{mu}$ ), accounting for 64.9\%; gryada and flat land cover 588 square kilometers ( 882 thousand $\mathrm{mu}$ ), accounting for 21\%; the water area covers 395 square kilometers (592 thousand mu), accounting for $14.1 \%$. The total population of the county is 612834 people (in year 2012) [1].

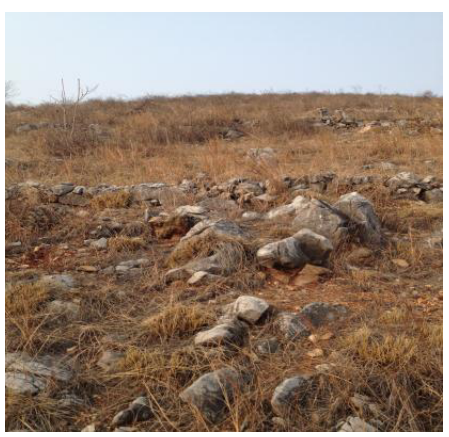

Figure 1. Rocky Desertification Status in Jinhe Town, Xichuan County

Xichuan County now has rocky desertification area of 2 million mu, accounting for nearly $50 \%$ of the county's total area, of which the severe rocky desertification area is 484 thousand mu, the moderate rocky desertification area is 689 thousand $\mathrm{mu}$, the shallow rocky desertification area is 827 thousand $\mathrm{mu}$, and the average annual soil erosion modulus is 
41 tons / ha [2-3]. The rocky desertification areas are distributed in the surrounding area of Danjiang reservoir, Danjiang River, Taohe River, Guanhe River, Qihe River and other river basins, including 12 towns and townships, such as: Jinhe, Shangji, Madeng, Dashiqiao, Laocheng, Jingguan, Siwan, Xihuang, Maotang, Taohe, Cangfang. The rocky desertification mountain rock in Xichuan County is most limestone and the soil is mostly tyrosinance subgroup ballast soil. Due to long eroding of rainfall, the base rock is exposed, and the gravel is aggregated, so the soil is barren and the vegetation is sparse.

In order to better grasp the first-hand information about the status of rocky desertification in Xichuan County, we conducted a field research in Xichuan County, and sampled the local soil, water, rock, vegetation, etc. for analysis.

Table 1. Soil Nutrient Test Report of Nanyang Soil and Fertilizer Monitoring and Analysis Center

\begin{tabular}{|c|c|c|c|c|c|c|c|c|c|c|}
\hline Sampling site & \# & $\begin{array}{c}\text { Total } \\
\mathrm{N} \\
(\%)\end{array}$ & $\begin{array}{c}\text { Total } \\
\text { P } \\
(\%)\end{array}$ & $\begin{array}{c}\text { Total } \\
\text { Potassium } \\
(\mathrm{mg} / \mathrm{kg})\end{array}$ & $\begin{array}{c}\text { Rapidly } \\
\text { Available } \\
\text { phosphorus } \\
(\mathrm{mg} / \mathrm{kg})\end{array}$ & $\begin{array}{c}\text { Slowly } \\
\text { available } \\
\text { potassium } \\
(\mathrm{mg} / \mathrm{kg})\end{array}$ & $\begin{array}{c}\text { Rapidly } \\
\text { available } \\
\text { potassium } \\
(\mathrm{mg} / \mathrm{kg})\end{array}$ & $\begin{array}{l}\text { Organic } \\
\text { matter } \\
(\%)\end{array}$ & $\begin{array}{c}\mathrm{pH} \\
\text { value } \\
(\mathrm{pH})\end{array}$ & $\begin{array}{c}\text { Humidity } \\
(\%)\end{array}$ \\
\hline $\begin{array}{c}\text { Xichuan } \\
\text { Wangjialing } \\
\text { (peak) }\end{array}$ & 1 & 0.464 & -- & & 17.6 & 624 & 208 & 2.75 & 6.2 & -- \\
\hline $\begin{array}{c}\text { Xichuan } \\
\text { Wangjialing } \\
\text { Mountain } \\
\end{array}$ & 2 & 0.171 & -- & -- & 16.3 & 672 & 256 & 1.35 & $6.2-$ & -- \\
\hline $\begin{array}{c}\text { Xichuan } \\
\text { Wangjialing } \\
\text { Mountain } \\
\text { (mountain foot) }\end{array}$ & 3 & 0.198 & -- & -- & 17.2 & 396 & 196- & 1.03 & $-6.1-$ & -- \\
\hline $\begin{array}{l}\text { Shangji Yanshan } \\
\text { Mountain(peak } \\
\text { soil) }\end{array}$ & 4 & 0.243 & -- & -- & 35.8 & 824 & 248-- & 1.24 & 6.3-- & -- \\
\hline $\begin{array}{c}\text { Shangji Yanshan } \\
\text { Mountain } \\
\text { (hillside soil) }\end{array}$ & 5 & 0.220 & -- & -- & 33.2 & 788 & 316-- & 0.97 & 6.2-- & -- \\
\hline $\begin{array}{l}\text { Shangji Yanshan } \\
\text { Mountain } \\
\text { (mountain foot } \\
\text { soil) }\end{array}$ & 6 & 0.805 & -- & -- & 28.0-- & 532-- & 140-- & 2.04 & 6.2-- & -- \\
\hline $\begin{array}{c}\text { Jinhe Biaochi } \\
\text { Village (peak) }\end{array}$ & 7 & 0.366 & -- & -- & 41.1-- & 656-- & 368-- & 2.27 & 6.4-- & -- \\
\hline $\begin{array}{l}\text { Jinhe Biaochi } \\
\text { Village (in } \\
\text { mountain) }\end{array}$ & 8 & 0.879 & -- & -- & 31.9-- & 672-- & 224-- & 3.37 & 6.5-- & -- \\
\hline $\begin{array}{c}\text { Jinhe Biaochi } \\
\text { Village } \\
\text { (Mountain Foot) }\end{array}$ & 9 & 0.293 & & & 39.8 & 240 & 392 & 0.78 & 6.4 & \\
\hline $\begin{array}{l}\text { Madengxi Valley } \\
\text { (Peak) }\end{array}$ & 10 & 0.592 & -- & -- & 39.5 & 696 & 408 & 4.18 & 6.3 & -- \\
\hline $\begin{array}{l}\text { Madengxi Valley } \\
\text { (hillside) }\end{array}$ & 11 & 0.293 & -- & -- & 18.6 & 1456 & 204 & 3.13 & 6.3 & -- \\
\hline $\begin{array}{l}\text { Madengxi Valley } \\
\text { (base station) }\end{array}$ & 12 & 0.226 & -- & -- & 17.7 & 1528 & 200 & 1.64 & 6.3 & -- \\
\hline $\begin{array}{l}\text { Taohe } \\
\text { Baishagang } \\
\text { (Peak) }\end{array}$ & 13 & 0.141 & -- & -- & 17.2 & 2084 & 280 & 1.44 & 6.5 & -- \\
\hline $\begin{array}{c}\text { Taohe } \\
\text { Baishagang (in } \\
\text { mountain) }\end{array}$ & 14 & 0.211 & -- & -- & 15.8 & 1716 & 268 & 2.40 & 6.5 & -- \\
\hline $\begin{array}{c}\text { Taohe } \\
\text { Baishagang } \\
\text { (mountain foot) }\end{array}$ & 15 & 0.144 & -- & -- & 17.2 & 2072 & 232 & 0.52 & 6.4 & -- \\
\hline $\begin{array}{l}\text { Yangying Village } \\
\text { (peak soil) }\end{array}$ & 16 & 0.199 & -- & -- & 17.2 & 1380 & 220 & 2.75 & 6.5 & -- \\
\hline $\begin{array}{l}\text { Yangying Village } \\
\text { (in mountain) }\end{array}$ & 17 & 0275 & & & 18.1 & 1984 & 256 & 3.61 & 6.5 & \\
\hline $\begin{array}{l}\text { Yangying Village } \\
\text { (mountain foot) }\end{array}$ & 18 & 0.107 & & & 17.6 & 1620 & 108 & 1.44 & 6.4 & \\
\hline
\end{tabular}




\begin{tabular}{|c|c|c|c|c|c|c|c|c|c|c|}
\hline $\begin{array}{c}\text { Xianghua } \\
\text { Yangying Village }\end{array}$ & 19 & 0.113 & -- & -- & 9.9 & 2064 & 240 & 0.52 & 6.3 & -- \\
\hline Taohe Hujia & 20 & 0.110 & -- & -- & 17.2 & 1612 & 148 & 0.76 & 6.4 & -- \\
\hline Shengwan Jiawan & 21 & 0.193 & -- & -- & 18.1 & 528 & 112 & 0.15 & 6.7 & -- \\
\hline $\begin{array}{c}\text { Shengwan } \\
\text { Wamiao }\end{array}$ & 22 & 0.107 & -- & -- & 19.4 & 320 & 160 & 0.69 & 6.8 & -- \\
\hline
\end{tabular}

\subsection{Soil Analysis}

We used random sampling method in the 7 sever rocky desertification towns and townships, to collect 22 soil samples, and detected the nitrogen, phosphorus, potassium, organic matter, $\mathrm{pH}$ and moisture content in the samples. The inspection report is shown in Table 1.

According to this table, we can see that the sampled soil $(7,8,9)$ in Jinhe Town showed weak acidity; although the weak acidity of the soil does not have great effect on water quality, but it poses a potential threat to the water quality in the long term, so we should take appropriate measures to control.

Affected by depth of water storage in the middle line of South-to-North Water Diversion Project, part of the arable land will be flooded; in order to avoid the impact of originally applied fertilizers in the part of arable land to the water quality, Xichuan County transferred the fertilized soil in these area to the barren highland area to achieve a multiplier effect. We can see from Table 1, in the soil transferred area, the soil elements in the sampled soil in Jinhe Town has very little impact to the water quality and can meet the requirements of the water supply quality.

\subsection{Water Quality Analysis}

Table 2. Nanyang City Surface Water Testing Schedule Unit: mg/L

\begin{tabular}{|c|c|c|c|c|}
\hline Item $\quad$ River & $\begin{array}{c}\text { Qihe River } \\
\text { Xichuan Gaowan }\end{array}$ & $\begin{array}{c}\text { Danjiang River } \\
\text { Xichuan Zijingguan }\end{array}$ & $\begin{array}{c}\text { Danjiang River } \\
\text { Xichuan Shijiawan }\end{array}$ & $\begin{array}{l}\text { Laoguanhe River } \\
\text { Xichuan Zhangying }\end{array}$ \\
\hline PH Value & 8.10 & 8.07 & 7.96 & 7.88 \\
\hline Dissolved oxygen & 7.44 & 7.46 & 7.35 & 7.27 \\
\hline Potassium permanganate & 2.60 & 3.03 & 2.81 & 2.89 \\
\hline Biochemical requirement & 2.34 & 2.79 & 2.38 & 2.53 \\
\hline Ammonia nitrogen & 0.21 & 0.42 & 0.25 & 0.24 \\
\hline Petroleum type & 0.01 & 0.04 & 0.02 & 0.01 \\
\hline Volatile phenol & 0.0016 & 0.0016 & 0.0016 & 0.0014 \\
\hline Mercury & 0.00002 & 0.00002 & 0.00002 & 0.00002 \\
\hline Lead & 0.005 & 0.005 & 0.005 & 0.005 \\
\hline Chemical oxygen demand & 12.62 & 14.18 & 12.99 & 13.28 \\
\hline Total nitrogen & 1.87 & 3.53 & 3.35 & 1.67 \\
\hline Total phosphorus & 0.04 & 0.19 & 0.06 & 0.05 \\
\hline Copper & 0.0005 & 0.0005 & 0.0005 & 0.0005 \\
\hline Zinc & 0.025 & 0.025 & 0.025 & 0.025 \\
\hline Fluoride & 0.18 & 0.025 & 0.50 & 0.19 \\
\hline Selenium & 0.00025 & 0.40 & 0.00025 & 0.00025 \\
\hline
\end{tabular}




\begin{tabular}{|c|c|c|c|c|}
\hline Arsenic & 0.0005 & 0.00025 & 0.00025 & 0.00025 \\
\hline Cadmium & 0.005 & 0.00025 & 0.0005 & 0.0005 \\
\hline Hexavalent chromium & 0.002 & 0.003 & 0.010 & 0.006 \\
\hline Cyanide & 0.002 & 0.004 & 0.002 & 0.002 \\
\hline Anionic surface-active agent & 0.025 & 0.025 & 0.025 & 0.025 \\
\hline Sulfide & 0.01 & 0.01 & 0.01 & 0.01 \\
\hline Water quality category & II & III & II & II \\
\hline
\end{tabular}

According to the water quality summary (as shown in Table 2) of main rivers in "Nanyang City Environmental Quality Summary (2013 year)", on the basis of the "Surface Water Environmental Quality Standards", it can be judged that the water quality of main rivers in Xichuan County can basically meet the requirements of class II and class III water quality, and meet the requirements of current water supply.

\subsection{Rock Analysis}

By random sampling rocks in Jinhe Town, Xichuan County, for analysis(as shown in Table 3), the content of calcium oxide in the rock reached $60 \%$, so we can determine the rock in Biaochi Village in Jinhe Town is limestone.

\subsection{Vegetation Analysis}

Jinhe Town belongs to moderate rocky desertification area, with less vegetation in the rocky area. Through field investigation, the vegetation in the rocky desertification area mainly includes: pines, cypresses, apricots, tung trees, walnut trees and cherry trees, etc.

Table 3. Chemical Composition Table of Rock

\begin{tabular}{|c|c|c|c|c|c|c|c|c|}
\hline Rock name & $\begin{array}{c}\text { Silicon } \\
\text { oxide }\end{array}$ & $\begin{array}{c}\text { Calcium } \\
\text { oxide }\end{array}$ & $\begin{array}{c}\text { Ferric } \\
\text { oxide }\end{array}$ & Alumina & $\begin{array}{c}\text { Magnesiu } \\
\text { m oxide }\end{array}$ & $\begin{array}{c}\text { Manganes } \\
\text { e oxide }\end{array}$ & $\begin{array}{c}\text { Sulfur } \\
\text { trioxide }\end{array}$ & $\begin{array}{c}\text { Anhydrous } \\
\text { phosphoric } \\
\text { acid }\end{array}$ \\
\hline Limestone & 1.01 & 56.27 & 0.27 & 0.27 & 0.057 & 0.0065 & 0.009 & \\
\hline Granite & 69.62 & 1.81 & 2.60 & 15.69 & 0.022 & 0.022 & 0.14 & 0.02 \\
\hline Quartz & 98.43 & 0.21 & 1.23 & 0.09 & & 0.006 & 0.21 & 0 \\
\hline
\end{tabular}

\section{Formation Mechanism of Rocky Desertification}

The aggravation of soil and water loss is the main factor that caused the rocky desertification, and the enlargement of the area of rocky desertification has further aggravated the soil erosion. The factors influencing the rocky desertification include natural causes and human causes.

\subsection{Natural Factors}

Xichuan County belongs to limestone mountainous county, where the lime soil can be easily leached, and the geographical condition is poor; the bedrock is exposed due to the perennial rainfall erosion and the surface is filled by gravel; because rocky desertification is the result of erosion and soil loss, they remain relevant. Therefore, the rocky desertification development trend is influenced and controlled by rock, soil properties, vegetation, terrain slope, rainfall duration, rainfall intensity and other factors[4].

\subsubsection{Soil and Terrain Analysis}

The rock in Xichuan County is mainly the carbonate rock series, and it has strong resistance against wind erosion, and the soil forming process is slow, which is the objective background condition and the basic reason for the shallow soil and easy rocky desertification in Xichuan County. The surface of Xichuan mountainous area is rugged and broken, 
there are many mountains and the slopes are steep. The hilly area of the county covers 1815 square kilometers (2.723 million $\mathrm{mu}$ ), accounting for $64.9 \%$ of the total area of the county; the surface structure with many mountains and steep slopes is not conducive to the preservation of water and soil resources. The surface structure with many mountains and steep slopes aggravated the loss of water, soil and fertilizer, and under the impact of some human activities, vast karst mountains become rocky desertification.

The lime soil can be easily leached, and the geographical condition is poor; the bedrock is exposed due to the perennial rainfall erosion and the surface is filled by gravel; because rocky desertification is the result of erosion and soil loss, they remain relevant[5]. Therefore, the rocky desertification development trend is influenced and controlled [4] by rock, soil properties, terrain slope, and other terrain factors.

\subsubsection{Effect of Precipitation and Vegetation Rate}

Xichuan has rich rainfall, and the annual rainfall is between 391.3 to $1423.7 \mathrm{~mm}$; the average annual rainfall is 804.3 $\mathrm{mm}$; the initial flood time in this territory is very early and the final flood time is very late; the flood season is from June to September, during which the rainfall accounts for $58 \%$ of the total annual rainfall; the highest percentage is up to $79.8 \%$ in certain years; the geographical distribution of rainfall is not uniform, with the feature of more rainfall in northwest and less rainfall in southeast. The average rainfall is between 731.2 to $809.4 \mathrm{~mm}$; the average annual rainfall in the mountainous area is basically between $900 \mathrm{~mm}$ and $1300 \mathrm{~mm}$; the heavy rain occurs mainly in spring (accounting about $40 \%$ ) and summer (accounting over 55\%). The spring and early summer are the sowing seasons for large area of arable slope; the crops (corn, rape, green manure, etc.) are at the seedling stage, and the loose slope soil is not well covered, so the rainstorms in spring and early summer exacerbate the rocky desertification development.

The vegetation can slow down the velocity of runoff on slope surface and absorb the flowing rain and prevent erosion of rain to the surface. The more vegetation coverage, the more slowly the soil and water will lose. The effect of vegetation on soil erosion usually depends of the forest coverage and canopy density; the higher the forest coverage rate is, the greater the canopy density will be, and the slighter the soil erosion problem will be. If a large range of vegetation is destroyed, it will reduce the forest coverage, and the soil erosion problem will be more serious, and this will result in the some rocky desertification.

\subsection{Human Factors}

Xichuan County has a big population and backward economic development, and the population and limited land per capita form a contradiction; the irrational use of land promoted the development of rocky desertification. Especially in areas with low forest coverage and large population and steep slope terrain, the rocky desertification is very serious.

\subsubsection{Population Factor}

Xichuan County has total population of 746 thousand, of which agricultural population is 658 thousand, accounting for $88.2 \%$ of the county's total population. In recent decades, the county had very high birth rate and low mortality rate resulted in an obvious rising trend of population. The size of population density directly determines the demand for resources, so the region with high population density cannot guarantee enough land resources. In order to meet the needs of survival, the expansion of cultivated area increased the destruction of vegetation. With the continuous weakening of the ability of self rehabilitation of the environment, the rocky desertification has become more and more serious.

Rapid population growth, high population density and low population quality caused Xichuan fall into a vicious cycle: population increase - over reclamation - the degeneration of soil due to erosion - rock desertification - economic poverty.

\subsubsection{Economic Level}

As a state-level poverty-stricken county, the backward regional economy in Xichuan County has seriously restricted the development of agriculture and the improvement of living standards. The predatory operation, deforestation, excessive reclamation, turf damage, digging roots, straw burning and other phenomena frequently took place in that area, and the farming methods are very backward.

Agricultural activities for excessive reclamation are carried out in the absence of cultivation conditions or protective measures. The cultivation of steep slope and slope planting in Xichuan County is a serious problem. The annual tillage soil accelerates the loss of soil resources and increases the rocky desertification area.

The ecosystem in Xichuan has very poor self protection ability. Along with the continuous development of infrastructure construction, the demand for timbers continued to increase. In order to obtain economic benefits, some people deforested in a wide range regardless of the consequences. In addition, the traffic conditions in some areas of Xichuan are quite underdeveloped, and the people are living at a very low standard; most of the people use natural plants as fuel in their lives. These factors result in a wide range of deforestation, so the original vegetation was severely damaged and the carrying capacity of the local environment was decreased. 
In the 1950s, the construction of Danjiangkou reservoir caused $543000 \mathrm{mu}$ of land to be flooded in Xichuan (including $285000 \mathrm{mu}$ of arable land) and the relocation of 202000 residents; as the arable lands of these relocated residents were flooded, they planted crops on the steep slopes and deforested to make a living. Their behaviors damaged the vegetation and caused serious soil erosion and the rocky desertification in mountainous areas.

\section{Concluding remarks}

In order to protect the canal ecological environment, enhance the ability of local soil conservation, the ability of water conservation ability and reservoir water purification capacity, reduce non-point source pollution, improve local residents' living environment and increase their income, improve their life quality, explore the reasonable and efficient exploitation mode of ridge and slope region with rocky desertification to realize the regional ecological environment protection and the coordinated development of regional economy, it is necessary to select representative ridge and slope area within the narrow basin near the reservoir bank in Xichuan County and carry out special research on rocky desertification control.

\section{References}

1. Yong Hao, Guo Zhansheng, Yang Zhaoxing, Luo Zhifa. "Study on the Current Status and Control Measures of Rocky Desertification in Danjiangkou Reservoir Area - Taking Xichuan County, Henan Province as an Example". Hebei Agricultural Science, 2012:75-77

2. Yang Zhaoxing, Feng Dexian, Guo Zhansheng. "Rocky Desertification and Control Measures in Water Source Area in the Middle Line of South-to-North Water Diversion Project". Regional Research and Development, 2013:104107

3. Xu Yan, Wang Ruipeng, Ren Bupan; Canal Water Source Area and Main Canal Ecological Corridor Construction in the Middle Line of South-to-North Water Diversion Project". Journal of Xinyang Normal University (Natural Science Edition), 2014:235-238

4. Su Weici. The Current Status, Reasons and Optimized Control Model of Rocky Desertification in Karst Mountainous Area in Southwest China. Journal of Soil and Water Conservation, 2002:29-32

5. Li Anding, Zhu Xiaoke, Yu Lifei, Wu Shizhang. Current Status of Karst Rocky Desertification in Luodian County and Comprehensive Prevention and Control Measures. China Soil and Water Conservation, 2007:56-61 